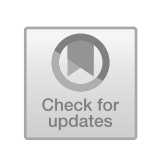

\title{
7
}

\section{Shipping as a Knowledge Industry: Research and Strategic Planning at Ocean Group}

\author{
Niels P. Petersson
}

\section{Introduction}

One of the most important transformations of the post-war world was the rise of what some contemporaries called the knowledge society. Knowledge created in the social and natural sciences now increasingly permeated society and with it the corporate world. This chapter approaches the question of how transformations in the world of shipping relate to wider trends in business and general history through the lens of knowledge. It will investigate how technological and managerial knowledge was created, developed and exploited as a corporate resource from the 1950s onwards in Ocean Transport and Trading, one of the UK's leading liner shipping firms. The chapter will, first, briefly discuss the resource-based view of the firm and the importance of knowledge as a corporate resource. It will then examine Ocean's use of technological and operational knowledge in the

\footnotetext{
N. P. Petersson $(\varangle)$

Sheffield Hallam University, Sheffield, UK

e-mail:n.p.petersson@shu.ac.uk 
post-war era. The following section examines the introduction of modern management concepts at Ocean from the late 1960s and their impact on corporate strategy. In conclusion, the chapter will argue that the introduction of managerial concepts of knowledge contributed to Ocean's gradual withdrawal from shipping and transformation into a provider of global logistics services and that analyzing shipping as a knowledge industry helps make sense of the transformation of the industry.

\section{Knowledge as a Resource}

The resource-based view of the firm was first developed by Edith Penrose in the 1950s. It has been widely adopted in management and organization studies since the 1980s to inform research into how firms can identify and develop their competitive advantage, enhance their performance and nurture 'dynamic capabilities' that allow them to adapt to changing market conditions. ${ }^{1}$ The key assumption of the resource-based view is that the firm is best analyzed as a set of specific resources under the control of the management. One of the key resources identified by Penrose was knowledge. Later work has placed knowledge at the centre of an economic theory of the firm, regarding the firm as an organization concerned with integrating individuals' specialist knowledge for use in the production of goods and services. ${ }^{2}$

The literature distinguishes a number of types of knowledge and ways of using knowledge. Tacit knowledge is implicit, informal, personalised, and usually based on experience and skills rather than formal learningqualities that would make it difficult to replicate and communicate, giving a firm controlling such knowledge a competitive advantage. At the same time, tacit knowledge does not easily feed into training, research, and discussion, making its systematic development and adaptation difficult. Explicit knowledge, on the other hand, is easily communicated, managed, stored, distributed, often actively created through research and reporting,

\footnotetext{
${ }^{1}$ Penrose (1959). For an overview of Penrose's impact, see Christos Pitelis's introduction in the 2009 edition of her work, ix-xlvii. Notable later contributions include Wernerfelt $(1984,1995)$ and Barney $(1991,2001)$ as well as Teece (2016).

${ }^{2}$ Grant (1996) and Spender (1996).
} 
and ultimately also bought and sold. It is easier to use, but not necessarily a durable foundation of competitive advantage unless its use can be restricted, for example through patents.

The resource-based view emphasizes the crucial role of a firm's management, describing it as 'the primary task of management ... to maximize value through the optimal deployment of existing resources and capabilities, while developing the firm's resource base for the future'. ${ }^{3}$ Managers' capacity to do so under conditions of 'deep uncertainty' over the development of markets, inputs and outputs has been discussed under the heading of a firm's 'dynamic capabilities'.

Scholars working within this framework have occasionally pointed to the benefits to be derived from historical research as 'the conditions under which resources are developed or acquired in one period have implications for the strategic advantages of firms in subsequent periods', and resources may lose their value if the market that determines their usefulness disappears. 'Firm-level history' has been proposed as one way of finding out 'how firm resources and capabilities are accumulated and eroded' and 'how resources' relative values may be affected by market changes'. ${ }^{6}$ At the same time, work on knowledge as a resource also suggests a number of questions that are potentially useful for business historians. On a basic level, these relate to the extent to which knowledge was recognized as a key resource by managers and entrepreneurs and to changes in the type of knowledge used, the personnel hired and the organizational structures created to develop or deploy such knowledge. More difficult, but also more interesting, are questions around the consequences of such changes in the use of knowledge- how did they affect corporate strategy and, ultimately, corporate success? Such questions provide a useful framework for analyzing the development of shipping in the post-war era. Like many other industries, shipping underwent profound and complex, internal and external transformations. As explained in Chapter 1 in this volume, the technology, business organization, and geographic focus of the industry changed,

\footnotetext{
${ }^{3}$ Grant $(1996,110)$.

${ }^{4}$ Teece $(2016,204)$. Jones et al. (2013) and Henrik Sornn-Friese in this volume analyse dynamic capabilities in a shipping context.

${ }^{5}$ Barney $(2001,51)$.

${ }^{6}$ Priem and Butler $(2001,35)$.
} 
resulting in profound shifts in competitive advantage. How did managers make sense of such transformations, how did they respond, what role did knowledge play in their response, and which were the consequences of the knowledge they used and the way they used it? Over the rest of this chapter, a resource-based perspective will be used to explore the changing use of knowledge in the industry.

\section{Technology and Operations}

\section{Improving Traditional Liner Shipping}

In the 1950s, the technology of cargo shipping that had not seen much innovation for decades began to change, mainly due to two developments: rising volumes of trade and rising wages, in particular for manual labourers such as dockworkers and seafarers. Shipowners responded by running larger, faster ships with smaller crews and more automated systems. From the 1950s onwards, 'supertankers' and large bulk carriers increased efficiency and brought down costs. In liner shipping, Ocean's main business, such rationalization was impossible as long as cargoes were highly diverse and essentially had to be stowed by hand. By the mid-1960s, tanker size had increased by $82 \%$ and tramp and bulk carrier size by $52 \%$, but cargo liner size only by $14 \%$. Cargo liners spent $60 \%$ of their time in port, and freight handling could account for over one-third of the total annual cost, including depreciation, of running a cargo liner. ${ }^{7}$

Ocean's naval architects in the 1950s knew that their ships were outdated and initiated a programme of research into optimal ship design. Ocean was among the first shipping companies to research the performance of its ships under real-world conditions, using current data as well as company archives to construct data series. Even by the late 1960s, most shipping companies lacked trained technical staff and had done little research in areas that were crucial for their operations and profitability, while much of the research undertaken by public bodies and shipowner associations lacked relevance or studied technologies without looking at

${ }^{7}$ van den Burg $(1969,11)$. 
their economic costs and benefits. ${ }^{8}$ Research on operating costs had mostly focused on fuel economy, which however was not a major concern in times of cheap fuel. Ocean's research now allowed to quantify the disproportionate increase of stevedoring costs and of time lost in port. Sea time had fallen from 200 days per year in 1950 to 180 in 1962. Keeping stevedoring costs in check, speeding up loading and reducing crew size therefore became the key considerations in designing the last generation of Ocean's cargoliners to enter service before the container age. ${ }^{9}$ The new ships, the Priam and Glenlyon classes, were designed with large and easily accessible cargo spaces. This made them more expensive to build as they were larger and heavier than strictly necessary to accommodate their cargo, but their spacious, more regularly shaped holds allowed savings where it mattered - the cost of time and labour when loading and unloading. ${ }^{10}$ The newer ships also could sail with smaller crews than their predecessors. While officer numbers were unchanged, only 29 ratings were required, against over 60 on older ships. Reducing crew size was a concern as the share of wages had risen from $10 \%$ of voyage costs in 1930 to $26.7 \%$ in 1963 and a shortage of seafarers had begun to emerge. ${ }^{11}$

Naval architects praised Ocean's research-based approach to the design of new ships, highlighting the commercial advantages ... which could accrue from proper investigation of the design aspects at the right time and not, as so frequently happens, after construction of the ship has commenced'. ${ }^{12}$ However, these efforts had their drawbacks. With the Priam class ships, the 'thinking and designing period, combined with the building period, covered no less than $4 \frac{1}{2}$ years. ${ }^{13}$ Over these years, market conditions had changed substantially. The Suez crisis briefly dented growth and decolonization and political unrest in Malaysia, Singapore and Indonesia cast doubts over the economic development of key ports to be serviced

\footnotetext{
${ }^{8}$ Goss (1998), Goss (2011), and Committee of Inquiry into Shipping (1970, 199-204).

${ }^{9}$ Meek $(1964,243)$.

${ }^{10}$ Ibid., 242, 246.

${ }^{11}$ Falkus $(1990,310)$; see King $(2000,58-60)$ on the labour market for seafarers.

${ }^{12}$ Meek $(1964,279)$.

${ }^{13}$ Meek and Adams $(1969,271)$.
} 
by the new ships. ${ }^{14}$ After a period of hesitation the ships were redesigned to make them faster and offer more refrigerated cargo space so that they could be used on different routes. ${ }^{15}$ The Glenlyon and Priam class ships were superseded almost as soon as they were delivered and eventually saw their service lives cut short by containerization.

Alongside technological change, operational improvements were constantly being made based on in-house research. Ocean created a dedicated research department in 1964, and a cargo superintendent was appointed to investigate the causes of the rise in cargo handling costs in various ports and suggest remedies. ${ }^{16}$ Yet, while substantial reductions in operating costs were achieved, these were far from game-changing and could not keep pace with the rapid increase in the costs of labour, credit, fuel etc. through the 70s. Even radical proposals such as the 1970s German study of the 'ship of the future' run by a minimal, versatile crew, and similar British studies of the 'Efficient Ship' undertaken in the 1980s were unable to fully compensate for such cost pressures. ${ }^{17}$

Overall, Ocean's experience with in-house research was mixed. Only limited potential for increased efficiency in traditional liner shipping was discovered. The main obstacles to increased efficiency and profitability in liner shipping were to be found not on board but in the way cargo and labour were organised in port. Meanwhile, the decision to design in-house and order purpose-built ships slowed down the introduction of technological innovation. Ships embodying state of the art 1950s operational and technological research were brought into service at a time when the fundamental break-through of containerization was already around the corner. Moreover, it was not necessarily rational for shipping companies to do their design and research in-house when such explicit and transferable knowledge could be bought off-the-shelf or developed by specialized outside organizations. Ocean's chairman himself came to realize that designing ships in-house had 'produced too many expensive mistakes'

\footnotetext{
${ }^{14}$ For the development of Ocean's main markets in these years, see Nick White's chapter in this volume.

${ }^{15}$ Falkus (1990, 323-328).

16Ibid., 310.

${ }^{17}$ For the Ship of the Future, see Ocean's summary 'A note on the V.D.R. experiment', 27 November 1974, 4.B.2328, for the Efficient Ship Daily Telegraph (2013).
} 
and getting shipyards to build one-off designs had become prohibitively costly. ${ }^{18}$ Finally, the application of knowledge remained patchy, and key economic factors such as the expected life of ships, their second-hand or scrap value, and the estimated distribution of revenues and operating costs over their service lives were not considered at all. ${ }^{19}$ This had an effect on Ocean's profitability, its ability to finance fleet replacement, and ultimately the value of the company as a whole.

\section{The Leap into Container Shipping}

If innovation in conventional liner shipping was methodical but limited and slow, containerization represented a deliberate and abrupt leap into the dark, both in commercial and in technological terms. Initially, Ocean was sceptical about the potential of containerization. However, early studies had assumed that containers would be used alongside conventionally packed cargo in conventional ships. ${ }^{20}$ Moreover, the problems that made containers attractive were only getting worse: port labour costs continued to rise, without any increase in productivity. In London, the real cost of loading cargo tripled during the 1960s. On the London-Sydney route, cargo handling costs represented 36\% of round voyage costs in 1960 and $64 \%$ in 1970 . Escalating stevedoring costs were aggravated by strikes. Liner ship owners saw the cost of cargo handling as the key reason for their lack of profitability and were looking for a long-term solution. ${ }^{21}$ When American competitors Sea-Land began to plan the containerization of Australian traffic, Ocean was quick to realise that this required a response. Chairman Sir John Nicholson argued that containers were 'bound to present such cost advantages to shippers / receivers ... as to be an inevitable development', and he concluded: 'If we (or other shipowners) don't provide such a service, someone else will, and eventually may be in a position to dominate liner conferences'. ${ }^{22}$ P\&O's chairman Sir

\footnotetext{
${ }^{18}$ Memo J. Nicholson, 31 May 1972, OA/JLA/box 7.

${ }^{19}$ Meek $(2008,136)$.

${ }^{20}$ Falkus $(1990,360)$.

${ }^{21}$ Gardner (1985, 195-197).

${ }^{22}$ Memo J. N. Nicholson, Container \& Unit Load Service, 3 May 1965, OA/OCL box 61.
} 
Donald Anderson shared this view. In his opinion, cargo handling costs were becoming 'unacceptable' to customers and mere 'improvements on the existing system' were insufficient. 'We believed that the liner trades were coming under such pressure that they must soon be revolutionised, and that containerisation was likely to be the most practical form which the revolution could take'. ${ }^{23}$

The outcome was the establishment of Overseas Containers Ltd. (OCL), a consortium consisting of Ocean, P\&O, Furness Withy and British \& Commonwealth. ${ }^{24}$ OCL began its life in 1965 as 'a Research organisation set up to carry out a feasibility study', not surprising given that its task was to create a revolutionary transport system, starting with a 'clean slate'. ${ }^{25}$ From mid-1966, when it was decided to go ahead with containerization on the UK-Australia route, OCL underwent a 'rapid transformation' into a proper shipping consortium. Within two years, OCL had to acquire 'hardware ... particularly ships, containers and a new overall system of refrigeration'. A 'comprehensive control and information system', shore establishments in the UK and Australia, a trunk haulage system in the UK, a 'radically new system of documentation', and 'a radically new organisation for cargo procurement' had to be designed and implemented. Policy issues (industrial relations, personnel, pensions, PR) had to be resolved and a financial and accounting structure created. ${ }^{26}$ Sales staff had to be trained or re-trained and customers had to be familiarized with the new way of shipping cargo, through measures including trial container shipments on traditional ships and advice on how best to load containers. $^{27}$

Shipbuilders were faced with completely new challenges: 'When work first began early in 1966 on the design of these ships there was not a great deal of precedent to work on ... the commercial planners who were endeavouring to match the number of containers and size and speed of ship to

\footnotetext{
${ }^{23}$ D. F. Anderson, Draft private \& confidential: Containerisation, 13 September 1966, OA/OCL box 61 .

${ }^{24}$ For the history of OCL, see Bott (2009).

${ }^{25}$ Circular to all senior staff, Organisation of O.C.L., 17 June 1966, OA/OCL box 61; ibid., 37; Miller (2012, 333, 339, 341).

${ }^{26}$ Circular to all senior staff, Organisation of O.C.L., 17 June 1966, OA/OCL box 61.

${ }^{27}$ Bott $(2009,106)$.
} 
the likely trade were also starting from scratch'. ${ }^{28}$ Research into container ship technology lagged behind the building of such ships. Knowledge of the required rigidity of container ships remained inconclusive well into the 1970s, 'long after these ships were first designed'. Experiments—such as setting up various configurations of cranes and mocked-up loading bays in an industrial yard to find the best way to get containers into the ship and hold them in place-had to be undertaken to inform design because neither theoretical models nor practical experience did yet exist. ${ }^{29}$

Under these circumstances, a number of measures had to be taken to mitigate commercial and technological risks. Ample safety margins were designed into these ships and, apart from the entirely new system for storing and fixing the containers, they were built to a deliberately conservative design, with a single-screw steam engine. They were also designed to allow conversion into bulk carriers in case containerization failed to take off. Many of these design choices had to be amended at a later date. Sometimes, this was fortunate: excessive safety margins allowed to increase cargo capacity by adding an extra layer of containers when demand turned out to be even larger than anticipated. On the other hand, the steam turbine engines were far too thirsty and powerful for the post-1973 era of high bunker costs and 'slow steaming'. They had to be replaced with diesel engines in the 1980s. The most conservative, 'safe' aspect of these ships' design was not necessarily commercially the most successful. ${ }^{30}$

Both technologically and commercially, containerization was begun under conditions of radical uncertainty - the new container ships' schedules, competition, loading times or the ports they were to call at were yet unknown when the naval architects got to work. However, 'for the first time in dry cargo ship design the nature of the cargo [was] known precisely. It [was] a predetermined number of boxes of standard size'. ${ }^{31}$ Thus, containers changed the role of knowledge in cargo handling. Before containerization, officers, ratings and dockworkers had to draw on their

\footnotetext{
${ }^{28}$ Meek $(1970,1)$.

${ }^{29} \mathrm{Ibid}$., 40, 17-22. Mostert (1974, 70-75, 144-145) notes that supertankers likewise were experimental ships of unproven (and often dubious!) quality.

${ }^{30}$ Meek $(1970,35)$.

${ }^{31}$ Ibid., 4.
} 
experience and specialized knowledge to solve ever-changing problems on the spot every time cargo-in the shape of bags, drums, boxes, cars, live animals for example — was moved into or out of the ship. With containers, handling and stowing could be automated and engineered with great precision. An enormous amount of knowledge was embodied in the design of interlocking systems, but once they were in place, little implicit knowledge or traditional craft was required to operate them. Such knowledge as was needed was of an explicit nature, easily recorded and taught, and largely the same on every ship and in every port.

Containers thus emancipated transport from 'the most costly, limited and disturbing factor in cargo handling, the unpredictable and rightly or wrongly pretentious human being. ${ }^{32}$ Standardization and routinization soon brought along computerization. Loading arrangements for Ocean's container ships were worked out by a computer and the data stored on disks that were transported by aeroplane to arrive before the ship. Operating ships changed from art to science and from craft to industry. One of Ocean's key resources, the knowledge of how to operate cargo liners economically and to high standards that had been developed and transmitted over decades, suddenly lost its value. ${ }^{33}$ It was replaced by knowledge that was explicit, codified and easily transmitted. Such commodified knowledge transformed shipping from bottleneck to engine of global connectivity, but it was no longer a resource that could underpin a company's long-term competitive advantage. Indeed, as Nicholas White points out in this volume, by the 1980s, with infrastructure in place and knowledge readily available, newcomers from Asia's developing countries found it relatively easy to enter the industry.

Nonetheless, containerization was profitable. After a difficult start, OCL continuously outperformed other shipping companies as well as the 'average for UK industrial and commercial companies'. ${ }^{34}$ More importantly, containers would soon change the way the world produced and consumed goods, and allow the emergence of present-day transcontinental supply chains and transnational corporations. Yet, the more shipping relied

\footnotetext{
${ }^{32}$ van den Burg (1969, 141); see also King (2000).

${ }^{33}$ This accumulated knowledge is described in Miller (2012, 95-103).

${ }^{34}$ Gardner (1985, 205 and Tables 4, 5).
} 
on explicit knowledge and codified procedure rather than tacit knowledge and ad-hoc problem solving, the more it became commodified, favouring large-scale, low-cost operators and putting pressure on conference arrangements. ${ }^{35}$ Finally, while shipping became cheaper, quicker and more predictable for shippers, for those involved in operating ships, it became routine and often boring. ${ }^{36}$

\section{Management and Strategy}

\section{Introducing Strategic Planning}

1965 marked not only the 100th anniversary of Ocean but also a number of momentous changes for the company, including the establishment of OCL as well as a reorganization of the fleet and flotation on the stock market. Flotation - undertaken to demonstrate a high share price before the introduction of capital gains tax in the UK-meant that Ocean became vulnerable to take-over by investors interested in the company's substantial cash reserves and unused tax allowances. To preserve its independence, Ocean had to make use of the resources it had accumulated. ${ }^{37}$ Ocean was also aware that successful containerization of major routes would not only destroy the value of its accumulated operational knowledge but also make most of its traditional business obsolete, with a few container ships replacing the entire fleet of nearly a hundred liners. While the Glenlyon class ships spent 191 days at sea per year, the Priams managed 216 and the Liverpool Bay container ships 300, achieving six to seven times as many ton-miles per year as the Priams. ${ }^{38}$ The pressure that had been building for the company to transform itself into something new now became irresistible. From the late 1960s onwards, Ocean adopted a new company structure, embarked on a diversification drive both within and outside shipping and eventually disengaged from all marine activities, including

\footnotetext{
${ }^{35}$ Barber (2003).

${ }^{36}$ See Lane (1986) and Gerstenberger and Welke (2002).

${ }^{37}$ Falkus (1990, 334-336).

${ }^{38}$ Meek $(2008,167)$.
} 
container shipping. The direction of these changes, and no small part of the impulse behind them, came from the systematic introduction and implementation of the factual and conceptual knowledge that informs the development of explicit business strategies.

Transformation meant diversification-using the company's resources (people, capital, tax allowances and so on) for other, ideally profitable, purposes. To guide diversification, an explicit strategy was required. Around this time, a whole new body of knowledge dealing with corporate strategy emerged and was disseminated in business books, taught in business schools and promoted by consultancy firms. ${ }^{39}$ Eventually, it became 'the framework by which companies understand what they're doing and want to do', but this process took time. ${ }^{40}$ In the UK, 'management thought remained the product of relatively few intellectuals' and no more than 3700 people were enrolled in management courses in 1966-1967..$^{41}$ Ocean and other shipping firms provided financial support for management courses at university level 'because ... management education in general is so important to this country', even while deploring that universities focused on postgraduate degrees and neglected the shorter and part-time courses for mid-career managers industry demanded. ${ }^{42}$

Turning towards diversification, restructuring and explicit strategic plans, the shipping industry followed the lead of many other international businesses. At Ocean, the introduction of modern management thought was the work of Sir Lindsay Alexander, a director responsible for commercial development and then chairman from 1971 to 1980, and of Nicholas Barber. Barber joined Ocean in 1964 as one of the 'crown princes' or 'student princes', promising Oxbridge graduates the company recruited from time to time with a view to fast-tracking them into senior

\footnotetext{
${ }^{39}$ For these developments, see Wilson and Thomson (2006, 117-123, 165-166) and Toms and Wright (2002, 101-105).

${ }^{40}$ Kiechel $(2010,4)$. On the history of strategic management thought, see Freedman $(2013$, ch. 28-36) and Mintzberg (1994).

${ }^{41}$ Child (1969, 113-114).

${ }^{42}$ Memo H. B. Chrimes, 11 June 1970, OA/JLA/box 22.
} 
management. ${ }^{43}$ Back in Liverpool after two years in Singapore, he persuaded Alexander to send him on an 18-month MBA course at Columbia University in 1969-1971 and then stepped into a new role as the company's Strategic Planner. ${ }^{44}$ His personal correspondence with Alexander sheds light on this crucial period in the company's development. ${ }^{45}$

Ocean's strategic planning systems were created from scratch, based on a review of how large US companies had introduced strategic planning. Priorities were quickly established: the emphasis was to be on identifying areas of development, because 'the whole need for strategic planning has arisen from our having to look for new business'; 'real support at the top' was considered necessary in order to get 'people interested in longer term problems which do not involve immediate operational pressures', and planning had to appear as Ocean's 'own activity rather than something done by people looking like management consultants' ${ }^{46}$

The Barber-Alexander correspondence led to a briefing document for Ocean's board, accompanied by a fuller version with background and reflections added. It started from the assumption that '[a]ll companies have a strategy but not usually explicitly,' and that an explicit strategy was particularly important when branching out into new business. Strategic planning was to help the Board '[d] etermine what kind of Company Ocean wants to become, particularly what businesses we expect to be in, for what rewards / risks'. It was to be an annual process, seeking to make top and middle management 'planning minded (including budget-minded), i.e. oriented to looking at the long term'. Planning was to become embedded in the company's processes and devolved from the Board and central departments downwards to senior and middle managers. The job of the Strategic Planning Division was 'to ask awkward questions / insist on

\footnotetext{
${ }^{43}$ On Ocean's recruitment strategies and the 'student princes', see Falkus $(1990,10,18,59,283$, 289).

${ }^{4}$ John Lindsay Alexander Papers, OA/JLA/box 7; personal communication, 25 October 2018.

${ }^{45}$ Barber to Alexander, 5 March 1970, 7 June 1970; Alexander to Barber, 9 March 1970, 18 June 1970; N. Barber, Basic approach to strategic planning, 30 March 1971, OA/JLA/box 7.

${ }^{46}$ Barber to Alexander, 23 August 1970, OA/JLA/box 7.
} 
answers / encourage management to do its own planning ... It will (must) not write its own answers. Paradoxically, planners should not plan'. ${ }^{47}$

Barber's (and Alexander's) starting point was that 'O[cean]'s major problem concerns strategic direction'. Asking 'what kind of Company Ocean wants to become' not only led to a 'master plan for the whole Company', but also to the setting of 'objectives for the future in terms of profit, return on investment and sales growth'. ${ }^{48}$ Once up and running, the system of strategic planning and budgetary control would allow for the first time to work on company strategy on the basis of detailed information on what the individual divisions were doing, how they were performing and developing, and how efficient they were. ${ }^{49}$ Along with strategic planning, a new company structure was introduced. While strategy was kept under the control of Ocean's managers, Boston Consulting Group was called in to help with development of the new structure. The result was a multidivisional company structure that would free up resources for strategic decision-making at Group level, with an Executive Committee free from operational responsibility, while planning and decision-making would be devolved to the operating divisions.

It is easy to dismiss these changes as little more than new jargon, or an imitation of changes occurring in many companies at the time: diversification, bureaucratization and the creation of multi-divisional structures. ${ }^{50}$ But the aims, and effects, of Ocean's strategic planning system were more far-reaching. The fact that the company's objectives were now stated in terms of profit, return on investment and growth should not be underestimated. So far, not making a loss and living up to self-set quality standards had been the only guidelines for company strategy. Now, economic performance indicators at least theoretically had gained primacy over other aims and unspoken assumptions. While fully implementing this new outlook would still take some considerable time, Ocean's managers now began to see themselves as business managers rather than shipowners.

\footnotetext{
${ }^{47}$ N. Barber, Brief for strategic planning, 9 March 1971, N. Barber, Strategic planning, 11 May 1971, OA/JLA/box 7. All quotations in this paragraph are from this document.

${ }^{48}$ Ibid.

${ }^{49}$ The operation of the system is described in the September 1972 Blue Book 'Strategic Planning and Budgetary Control' (photocopy in possession of the author, kindly provided by David Riddle). ${ }^{50}$ Channon (1973).
} 
The dangers of a lack of explicit criteria and strategy are illustrated by some of the attempts at diversification that Ocean had already undertaken, for example a move into services and hotels in the Caribbean, and diversification into new areas of shipping such as tankers, bulkers and liquefied natural gas. The Caribbean ventures never became profitable and nobody could in the end make sense of how they fitted in with the rest of the company. The acquisition of the LNG tanker Nestor, ordered in 1970, nearly broke the company_it was built for a market that did not materialize, went straight from the dockyard into layup and was sold off in 1989, never having seen service. It later turned out that basic errors were made in assessing the viability of the project. ${ }^{51}$

Strategic planning was supposed to prevent such mistakes by reviewing the strengths and weaknesses of the company, the resources it had, the markets it might move into, and the resources it would need to succeed. Thorough analysis of Ocean's resources soon revealed important weaknesses alongside the company's acknowledged strengths. Ocean's knowledge was concentrated in a narrow, unfortunately increasingly irrelevant, area: the operation of cargo liners in cartelized markets. In many other areas, the company lacked knowledge and well-trained staff. To enable Ocean to diversify and seize opportunities in other markets, new expertise was required in areas such as finance, accounting, taxation, internal audit, and personnel. Management in general was seen as a weakness, with a shortage of general management skills and a lack of experience in marketing, retailing, and 'working to fine margins'. Accordingly, the first exercises in strategic planning resulted in 'mostly very poor' plans and gave 'no demonstration that the line manager really understands the business he is in'. ${ }^{52}$ Falkus notes that before the early 1970 s, Ocean's rigid management structure and lack of 'financial and accounting expertise ... made the implementation of a coherent diversification plan well-nigh impossible. ${ }^{53}$ Ocean's people were good at operating ships but not at running a business. Like other shipping companies, or the trading houses active in disappearing colonial markets, Ocean had to accept that resources such as

\footnotetext{
${ }^{51}$ Falkus (1990, 342-344); Nicholas Barber, personal communication, 3 March 2016. Gardner $(1985,205)$ argues that it was diversification that held back liner shipping profits over the 1970s.

${ }^{52}$ Barber to Alexander, 15 May 1972, OA/JLA/box 35.

${ }^{53}$ Falkus (1990, 291).
} 
accumulated skills and experience were being devalued by political change such as decolonization and technological change such as containerization, and were not easily transferable into other complex industries. ${ }^{54}$

Despite disappointment with the initial results, the strategic planning exercise paid off quickly. Conducting a thorough assessment of threats, aims and resources enabled Ocean to seize the opportunity when the services company Cory came up for sale in 1972. Ocean quickly identified Cory as a perfect match, Cory was bought and over the coming years, Ocean's shipping activities were gradually scaled down and Cory provided the basis for the company's transformation into an industrial services business. Many of the managers brought in with Cory or recruited from other non-shipping sectors at the same time would soon play leading roles in Ocean. The mission of OCL, initially defined as achieving a dominant position in container shipping, was redefined as providing the best possible return on the parent companies' investment. ${ }^{55}$ By the end of the 1980 s, Ocean, in Barber's words, resembled a 'Polo Mint' — a company formed around a shipping core that no longer existed. ${ }^{56}$ Commercial knowledge, including a heightened awareness of resources, costs and profitability led to diversification away from the shipping industry — an activity Ocean was good at, but where the knowledge accumulated over more than a century was no longer relevant due to the commodification of operations bulk and container shipping had brought with them.

\section{Implementing Strategic Planning}

This brief big-picture summary should not distract from the considerable difficulties Ocean experienced trying to implement strategic thinking and budget-conscious management. By the mid-1970s, Ocean still used an 'amalgam of various accounting systems', consolidation of which remained a goal for the longer term. ${ }^{57}$ Developing human resources policies and procedures aligned with overall Group strategy took many years.

\footnotetext{
${ }^{54}$ A point made by Jones (2002, 220, 680-682, 761).

${ }^{55}$ Bott $(2009,144)$.

56 Personal communication, 3 March 2016.

${ }^{57}$ Ocean Group Finance Division, Strategic Plan 1976-1980, OA/OCL/box 9.
} 
The transition out of liner shipping took much longer than expected, as diversification within shipping failed dramatically and the newly-acquired Cory businesses were slow to take off while traditional liner shipping business declined more slowly than anticipated. The Cory businesses seemed more responsive to planning than the old Ocean core. The shipping divisions and in particular OFL, the staffing and maintenance division, often adopted a defensive attitude, sensing that — even though they still contributed the bulk of Group earnings and profits-their importance and opportunities were declining. Far from implementing the strict focus on return on capital required in the strategic planning process, in day-today management, Ocean tried to keep up 'fleet morale' and shore up its 'marine base'. In the short run, it seemed very costly to wind down marine activities while maintaining the reputation and identity of a 'responsible employer', but in the longer run, opportunities to sell ships while they still commanded reasonable prices were lost, and staff had to be made redundant nonetheless, and in overall much worse labour market conditions. ${ }^{58}$

Elaborate strategic plans for all parts of the business had become part of Ocean's operational routines by the mid-1970s. These plans noted that the process of planning had made operations more efficient generally, but also that planning and forecasting had usually tended to 'over-react to the prevailing conditions at the time of planning. ${ }^{59}$ More importantly, while strategic planning could yield sharper insight into the nature of existing difficulties and deficiencies, it often was less successful in finding alternative uses for Ocean's resources. Mid-1970s strategic plans paint the picture of a company that had few strategic options and was trapped by laws and regulations in a declining sector and in an inflation-ridden economy controlled by trade unions and a socialist government. The Group Personnel Division's plan for 1977-1981 noted that the strategic planning system and its aim to allocate resources to the most promising markets was based on the assumption of free markets, in particular for labour, which was no longer correct. Even the basic notion of growth which was at the heart

\footnotetext{
${ }^{58}$ Marine Committee meetings, 28 November 1977, 24 June 1978, 7.A.1951-1. For further references, see Petersson (2018).

${ }^{59}$ Group Strategic Plan 1977-1981, 4.B.1860.
} 
of both Ocean's internal planning and BCG's proposals had apparently become 'suspect' in much of public discourse. ${ }^{60}$

'The lack of indicated growth opportunities, combined with the capacity to invest, is a major planning gap', noted the 1976-1980 Group Strategic Plan. Probing questions were asked, but not answered: did Ocean need new businesses or a new 'product' 'to answer our longer term growth requirements, and to enable us to escape from the increasing likelihood of State interference and constraint in the service industries of transportation and distribution?' Could the answer be a move to overseas investment in familiar businesses? 'Or, does a new activity imply a new business altogether, such as manufacturing? leisure? mining? engineering? or what? ${ }^{\prime 61}$ These are the question the diversification literature at the time recommended asking, and strategic planning made sure that such questions were asked, the company's situation was analyzed and growth opportunities were sought. ${ }^{62}$ Ocean had begun to function as a business seeking ways to achieve the best possible return on the capital employed. Yet, solutions were not easy to find. Plans continued to highlight the need to develop new activities in order to 'balance the preponderance of mature and declining businesses', and to affirm: 'We have very substantial capacity to invest and few identified growth opportunities to enable us to exploit these resources'. Asking entrepreneurial questions seemed easier than finding entrepreneurial answers. ${ }^{63}$

\section{Management Development}

There was a practical as well as a strategic side to the increased attention paid to management knowledge as a corporate resource at Ocean in the 1970s. Until then, training had been largely on-the-job, with no systematic, formal training of management staff for specific roles. Barber

\footnotetext{
${ }^{60}$ Group Personnel Division Strategic Plan 1977-1981, in Rees (1987), Appendix 61, 10.

${ }^{61}$ Group Strategic Plan 1977-1981, 4.B.1860.

${ }^{62}$ Rich (1978a, b).

${ }^{63}$ Group Strategic Plan 1977-1981, 4.B.1860.
} 
bemoaned a lack of entrepreneurial spirit, along with an atmosphere characterized by amateurism and paternalism. ${ }^{64}$ A systematic effort to train and empower managers was made alongside the introduction of strategic planning. Yet John D. Rees, who joined Ocean as management development adviser in 1973, claims that the devolution of responsibility and leadership too often was only a theoretical goal, whereas in practice the Board were reluctant to give up control ${ }^{65}$ - perhaps understandably, given the deficiencies revealed by the first strategic plans. Rees saw the increased role of formal knowledge as the signature of modern business. He tried to get everyone on Ocean's management development programme to read Peter Drucker's The Age of Discontinuity - the main theme of which was the rise of the knowledge society—as well as Alvin Toffler's Future Shock which, he hoped, would 'shake complacent managers into an awareness of changes in their work environment and in the wider context of a post-industrial society'. ${ }^{66}$ Rees's management development programmes focused on aspects that had become important under the new decentralized multidivisional structure. In particular, personnel management techniques and procedures were introduced, with all line managers becoming responsible for appraising their staff and setting objectives closely aligned with company and divisional strategic plans. Likewise, all managers had to brush up on finance and accountancy. ${ }^{67}$

It is not easy to assess the overall effect of these changes. The transformation Ocean managers described as one from 'family business style' to 'big business style ${ }^{68}$ - a development that mirrored the gradual engagement with management weaknesses throughout British industry at the time $e^{69}$ was more difficult to achieve in practice than to sketch out on paper. The impact of managers brought in through the Cory acquisition shows that it is often easier to acquire resources from outside than to develop them from

\footnotetext{
${ }^{64}$ Nicholas Barber, personal communication, 3 March 2016.

${ }^{65}$ Rees (1987, 33-35).

${ }^{66}$ Drucker (1969) and Toffler (1970). The quote is from Rees $(1987,87)$.

${ }^{67}$ Rees (1987) provides a narrative as well as detailed examples of the training courses introduced while he was at Ocean.

${ }^{68}$ Falkus (1990, 350).

${ }^{69}$ Wilson and Thomson (2006, 41-42).
} 
scratch internally. ${ }^{70}$ Yet it appears plausible that both personnel management and financial knowledge were essential to operating a business in the 1970 s and beyond as labour relations were becoming more bureaucratic and the company was focusing on the financial 'bottom line'. What is clear is that the Ocean of the 1970s and onwards fully understood the necessity of systematically developing, distributing and applying modern management knowledge throughout its senior workforce, as well as of recruiting, nurturing and promoting skilled staff.

With strategic planning, diversification, management development and implementation of the multi-divisional structure, the days where the knowledge that underpinned Ocean's competitive advantage was about operating liner ships in a cartelized environment were gone. Systematic strategic planning processes were now governing both 'grand strategy' at a group level, and detailed mapping out and budgeting of individual divisions' development over the medium term. But did the adoption of strategic planning achieve its objectives and lead to a sustainable improvement in performance? David Riddle, Barber's successor as Ocean's strategic planner, argues that the 'successful development of a broadly based freight group [was] the result of the creation of business plans driven by long term profitability and the move away from basic ship operations. ... I put it down to the introduction of planning and related reporting in the early $1970 s^{\prime} .^{71}$ The literature on strategic planning is often much more sceptical about what could be achieved through the strict application of strategic planning methodology, arguing that its formalistic nature tended to prevent, rather than support, strategic thinking and suffocate entrepreneurialism. ${ }^{72}$ Planning is described as designed for the stable growth conditions of the 1960s and unsuited to the radical uncertainty and heightened competition of the 1970s. Ocean's experience seems to lend qualified support to both sides of the argument. On the one hand, the most fundamental strategic decisions were taken either before strategic planning was fully in place or did not figure in the strategic plans (as with

\footnotetext{
${ }^{70} \mathrm{~A}$ point made by Wernerfelt $(1984,175)$.

${ }^{71}$ Personal communication, 1 August 2016, 30 November 2018.

${ }^{72}$ This is the main argument in Mintzberg (1994); see also Freedman $(2013,518)$.
} 
the acquisition of Cory), and planning did not provide much help in identifying growth and investment opportunities in the 1970s. On the other hand, though, strategic planning seems to have provided the tools required to identify and assess strategic opportunities. Again, the Cory acquisition is a prime example because though it was clearly an opportunistic move it could not have been identified as a strategic opportunity without the work already undertaken in the context of the introduction of strategic planning. At the level of individual businesses, planning helped implement strategic decisions and keep a focus on commercial performance. Within the resource-based framework adopted in this chapter, it can be argued that strategic planning helped mobilize and apply knowledge about the company, its divisions, its customers, competitors and environment both in strategic decision-making and in day-to-day implementation. It thus seems to have fostered the systematic development of knowledge as a corporate resource. As such, planning underpinned and enabled strategic thinking and decision-making - what it could not, and at least in Ocean's case was not intended to, achieve was replace them.

\section{Conclusion}

Lutz Raphael highlights that all aspects of modern society are transfused with concepts and findings derived from research (calling this, in untranslatable German, 'Verwissenschaftlichung des Sozialen'). ${ }^{73}$ This chapter has examined the role of formalized, research-based technological, operational and conceptual managerial knowledge in Ocean's transformation. Many of the changes discussed above were initiated by managers who studied academic publications on technology, business and society, while academic researchers closely followed transformations in the corporate world. ${ }^{74} \mathrm{At}$ Ocean, knowledge was increasingly seen and nurtured as a key corporate resource and explicit strategy was embodied in rolling five-year strategic plans. Across all processes within the company, explicit and documented knowledge took the place of tacit, experience-based knowledge. From the

\footnotetext{
${ }^{73}$ Raphael (1996).

${ }^{74}$ The preface to Channon (1973) provides an example.
} 
1950s, systematic research informed incremental changes in ship design and operations. However, its impact remained limited. Only containerization would eventually remove key bottlenecks in cargo liner shipping. Ocean was among the firms that pro-actively adopted and implemented containerization, developing an interlocking system of technological and operational innovations to make it work. This, however, had the effect of devaluing the largely implicit, ad-hoc knowledge that underpinned the competitive advantage of traditional liner shipping firms and replacing it with standardized, commodified knowledge - an example of 'how firm resources and capabilities are accumulated and eroded' and 'how resources' relative values may be affected by market changes' ${ }^{75}$

While modern technology usually consists of explicit knowledge and thus is easily accessible to those able to study it or to pay for it, it is much more difficult to work out how or whether to use it. A resource-based perspective stresses the key role played by operational and strategic knowledge in shaping and reacting to wider transformations. Here, Ocean's focus shifted from nurturing the craft of shipping towards running a business. With the introduction of strategic planning, budgets, cost, profits and return on capital moved centre stage. This shift in perspective eventually transformed Ocean, but it was a gradual process involving change in personnel, large-scale training and cultural change as well as the change of procedures and explicit strategy. The implementation issues encountered along the way raise the question to what extent even companies operating with a large body of explicit knowledge and well-document procedures rely on tacit knowledge allowing employees to identify necessary shortcuts and work to the spirit, rather than the letter, of the rules. Another aspect that deserves to be highlighted is the effect of new types of knowledge on power within the corporation. The introduction of strategic management, performance planning and explicit targets for growth and profits served to assert and legitimate the power of managers, and bolstered the interests of shareholders. ${ }^{76}$

\footnotetext{
${ }^{75}$ Priem and Butler (2001).

${ }^{76}$ Child (1969, 22-23, 232-233) and Knights and Morgan (1991); see also Freedman (2013), Mintzberg (1994), and Bott (2009, 189, 205-207).
} 
A focus on knowledge allows highlighting the agency of managers, as well as the limits on that agency and the complexity of their task under conditions of fundamental uncertainty. What they could not know, for example, was to what extent their initiatives would succeed, which transformations would unfold and which ones would falter, and how new knowledge would ultimately become embodied in new types of institutions and organizations. Containerization and diversification were initiatives dating back to the 1960s, a time of optimism and stable expansion, but had to be implemented in the 1970s, a period of depressed growth, high inflation and unpredictable structural change. The organizational transformations of the 1970s were the key factor that unlocked the potential of the technological changes made in the 1950s and 1960s, eventually transforming shipping into an engine of globalization and the key mechanism in global chains of production and consumption. However, the transformations the industry underwent along the way were largely unforeseen. In fact, applying business knowledge to the shipping industry changed the industry so much that it became unviable for many of the first movers to remain active in it.

Acknowledgements I would like to thank Nicholas Barber CBE and David Riddle (ex-Ocean) for sharing their ideas and answering my questions and Dr. Chris Corker and Prof. Stig Tenold for reading suggestions.

\section{References}

\section{Archival Sources}

All archival sources referred to are part of the Ocean Group papers located in the Merseyside Maritime Museum archives, Liverpool.

\section{Published Sources}

Barber, N. (2003). Ocean as a Liner Shipping Company. Nestorian, 20, 11. 
Barney, J. B. (1991). Firm Resources and Sustained Competitive Advantage. Journal of Management, 17, 99-120.

Barney, J. B. (2001). Is the Resource-Based "View" a Useful Perspective for Strategic Management Research? Yes. The Academy of Management Review, 26 (1), 41-56.

Bott, A. (Ed.). (2009). British Box Business: A History of OCL. SCARA.

Channon, D. F. (1973). The Strategy and Structure of British Enterprise. London: Macmillan.

Child, J. (1969). British Management Thought: A Critical Analysis. London: Allen \& Unwin.

Drucker, P. (1969). The Age of Discontinuity: Guideline to Our Changing Society. London: Heinemann.

Falkus, M. (1990). The Blue Funnel Legend: A History of the Ocean Steam Ship Company, 1865-1973. London: Macmillan.

Freedman, L. (2013). Strategy: A History. New York: Oxford University Press.

Gardner, B. (1985). The Container Revolution and Its Effects on the Structure of Traditional UK Liner Shipping Companies. Maritime Policy \& Management, 12(3), 195-208.

Gerstenberger, H., \& Welke, U. (2002). Seefahrt im Zeichen der Globalisierung. Münster: Westfälisches Dampfboot.

Goss, R. O. (1998). Rochdale Remembered: A Personal Memoir. Maritime Policy \& Management, 25(3), 213-233.

Goss, R. O. (2011). Strategies in British Shipping 1945-1970. Mariner's Mirror, 97(1), 243-258.

Grant, R. M. (1996). Toward a Knowledge-Based Theory of the Firm. Strategic Management Journal, 17, 109-122.

Jones, G. (2002). Merchants to Multinationals: British Trading Companies in the Nineteenth and Twentieth Centuries. Oxford: Oxford University Press.

Jones, O., Ghobadian, A., O’Regan, N., \& Antcliff, V. (2013). Dynamic Capabilities in a Sixth-Generation Family Firm: Entrepreneurship and the Bibby Line. Business History, 55(6), 910-941.

Kiechel, W., III. (2010). The Lords of Strategy: The Secret Intellectual History of the New Corporate World. Boston: Harvard Business Review Press.

King, J. (2000). Technology and the Seafarer. Journal for Maritime Research, 2(1), 48-63.

Knights, D., \& Morgan, G. (1991). Corporate Strategy, Organizations, and Subjectivity: A Critique. Organization Studies, 12(2), 251.

Lane, T. (1986). Grey Dawn Breaking: British Seafarers in the Late Twentieth Century. Manchester: Manchester University Press. 
Meek, M. (1964). Glenlyon Class: Design and Operation of High-Powered Cargo Liners. Royal Institution of Naval Architects: Quarterly Transactions, 106 (3), 241-285.

Meek, M. (1970). The First O.C.L. Container Ships. Royal Institution of Naval Architects: Quarterly Transactions, 112(1), 1-41.

Meek, M. (2008). There Go the Ships. County Durham: Memoir Club.

Meek, M., \& Adams, R. (1969). "Priam” Class Cargo Liners-Design and Operation. Royal Institution of Naval Architects: Quarterly Transactions, 111(3), 271-298.

Miller, M. B. (2012). Europe and the Maritime World: A Twentieth Century History. Cambridge: Cambridge University Press.

Mintzberg, H. (1994). The Rise and Fall of Strategic Planning. London: Prentice Hall.

Mostert, N. (1974). Supership. London and Basingstoke: Macmillan.

Obituary: Marshall Meek. (2013, September 29). The Daily Telegraph.

Penrose, E. (1959). Theory of the Growth of the Firm. Oxford: Blackwell.

Petersson, N. P. (2018). Managing a "People Business" in Times of Uncertainty: Human Resources Strategy at Ocean Transport \& Trading in the 1970s. Enterprise \& Society, 19(1), 88-123.

Priem, R. L., \& Butler, J. E. (2001). Is the Resource-Based "View" a Useful Perspective for Strategic Management Research? The Academy of Management Review, 26 (1), 22-40.

Raphael, L. (1996). Die Verwissenschaftlichung des Sozialen als methodische und konzeptionelle Herausforderung für eine Sozialgeschichte des 20. Jahrhunderts. Geschichte und Gesellschaft, 22(2), 165-193.

Rees, J. D. (1987). A Study of Management and Organization Development in a UKShipping Transport and Trading Company, 1972-80 (MA thesis). Durham.

Report of the Committee of Inquiry into Shipping. (1970). London: H.M. Stationery Office.

Rich, C. A. (1978a). Corporate Planning in Shipping: Relating Theory to Practice, Pt. 1. Maritime Policy \& Management, 5(1), 31-38.

Rich, C. A. (1978b). Corporate Planning in Shipping: Relating Theory to Practice, Pt. 2: Corporate Strategy. Maritime Policy \& Management, 5(1), 39-50.

Spender, J. C. (1996). Making Knowledge the Basis of a Dynamic Theory of the Firm. Strategic Management Journal, 17, 45-62.

Teece, D. J. (2016). Dynamic Capabilities and Entrepreneurial Management in Large Organizations: Toward a Theory of the (Entrepreneurial) Firm. European Economic Review, 86, 202-216.

Toffler, A. (1970). Future Shock. New York: Bantam. 
Toms, S., \& Wright, M. (2002). Corporate Governance, Strategy and Structure in British Business History, 1950-2000. Business History, 44(3), 91-124. van den Burg, G. (1969). Containerisation: A Modern Transport System. London: Hutchinson.

Wernerfelt, B. (1984). A Resource-Based View of the Firm. Strategic Management Journal, 5(2), 171-180.

Wernerfelt, B. (1995). The Resource-Based View of the Firm: Ten Years After. Strategic Management Journal, 16(3), 171-174.

Wilson, J. F., \& Thomson, A. (2006). The Making of Modern Management: British Management in Historical Perspective. Oxford: Oxford University Press.

Open Access This chapter is licensed under the terms of the Creative Commons Attribution-NonCommercial-NoDerivatives 4.0 International License (http:// creativecommons.org/licenses/by-nc-nd/4.0/), which permits any noncommercial use, sharing, distribution and reproduction in any medium or format, as long as you give appropriate credit to the original author(s) and the source, provide a link to the Creative Commons license and indicate if you modified the licensed material. You do not have permission under this license to share adapted material derived from this chapter or parts of it.

The images or other third party material in this chapter are included in the chapter's Creative Commons license, unless indicated otherwise in a credit line to the material. If material is not included in the chapter's Creative Commons license and your intended use is not permitted by statutory regulation or exceeds the permitted use, you will need to obtain permission directly from the copyright holder. 